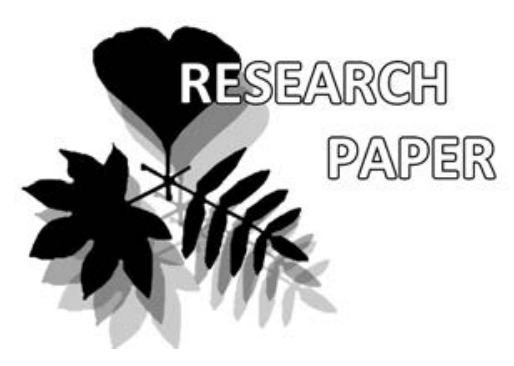

\title{
Lichens collected in the Sakhalin Botanical Garden: new records to Russia, the Russian Far East and Sakhalin Island
}

\author{
Svetlana I. Tchabanenko ${ }^{1}$, Liudmila A. Konoreva ${ }^{2,3,4}$ \& \\ Sergey V. Chesnokov ${ }^{1,4}$
}

Svetlana I. Tchabanenko ${ }^{1 *}$

e-mail: tuna54@mail.ru

Liudmila A. Konoreva $2,3,4$

e-mail: ajdarzapov@yandex.ru

Sergey V. Chesnokov ${ }^{1,4}$

e-mail: lukinbrat@mail.ru

${ }^{1}$ Sakhalin Branch of the Botanical Garden-Institute FEB RAS, Yuzhno-

Sakhalinsk, Russia

${ }^{2}$ Botanical Garden-Institute FEB RAS,

Vladivostok, Russia

${ }^{3}$ Polar-Alpine Botanical Garden and Institute, Kola Science Centre of RAS, Apatity, Russia

${ }^{4}$ V.L. Komarov Botanical Institute RAS, Saint-Petersburg, Russia

* corresponding authors

\begin{abstract}
A B S T R A C T
During the lichenogical survey conducted in the Sakhalin Branch of Botanical Garden-Institute FEB RAS, a number of interesting findings were made. Among the identified species, Thelotrema bicinctulum is new for Russia; Agonimia flabelliformis, Peridiothelia fuliguncta, and Strigula jamesii were recorded for the Russian Far East for the first time; Arthonia helvola, A. spadicea and Ionaspis epulotica are new to the South of the Russian Far East and five species to Sakhalin Island.

Ke y w o r d s : lichens, Far East, Sakhalin, new records, Asia

\section{P E 3 Ю M E}

Чабаненко С.И., Конорева А.А., Чесноков С.В. Находки мишайников на территории Сахалинского ботанического сада: новые виды ААя России, Аальнего Востока и острова Сахамин. При проведении Аихенологических исследований на территории Сахалинского филиала Ботанического сада-института АВО РАН был сАелан ряд интересных находок. Среди выявленных вилов Thelotrema bicinctulum явАяется новым Аля России, Agonimia flabelliformis, Peridiothelia fuliguncta и Strigula jamesii впервые приведены для Российского Аальнего Востока, Arthonia helvola, A. spadicea и Ionaspis epulotica - Аля юга российского Аальнего Востока, 5 видов впервые указаны Аля острова Сахалин.
\end{abstract}

КАючевые слова: Аишайники, Аальний Восток, Сахалин, новые находки, Азия

Manuscript received: 19.02 .2018

Review completed: 28.04.2018

Accepted for publication: 12.05.2018

Published online: 13.05.2018

Sakhalin Branch of the Botanical Garden-Institute of the Far Eastern Branch of Russian Academy of Sciences (Sakhalin Botanical Garden) is located in the southeast of Yuzhno-Sakhalinsk at the foothills of the Susunai Mountain Range. The garden covers an area of 40 hectares in the upper parts of two small streams at elevation of $52-128 \mathrm{~m}$ above sea level.

The natural vegetation is represented by secondary $B e-$ tula forest with Sorbus commixta Hedl. and Salix hultenii Flod. remained after felling conifer trees in a primary mixed forest, riverine Alnus and Salix forest with Fraxinus mandshurica Rupr., meadow and meadow-marsh communities, fragments of wastelands. Small areas are occupied by artificial plantations of 60-80 years old Larix leptolepis (Siebold \& Zucc.) Gord., as well as plant expositions and nurseries of tree species (25-30 years old).

The first studies of lichens in the garden were carried out in 1993-1995, and a list of 40 macrolichen species was compiled (Tchabanenko 1999). In 2017, we repeated lichenological studies on the territory of this experimental forest with special focus on microlichens. Here, we present the information on lichen species, new to Sakhalin Island, the Russian Far East and Asian continent.

\section{MATERIAL AND METHODS}

This study is based on lichen specimens collected in the Sakhalin Botanical Garden by L. Konoreva and S. Chesnokov in 07.05.2017 (Fig. 1). The material was collected in all types of natural and artificial communities in the garden territory. Various substrates: different tree species, mossy trunks, stones and soil, were examined. Specimens were deposited in the herbarium of Sakhalin Branch of Botanical Garden-Institute FEB RAS (SAKH). Material was examined using standard microscopic techniques with light microscopes MBS-10 and LOMO Mikmed 2. Photos of the lichen specimens were taken through the stereomicroscope MG 23.

The main studied localities (Fig. 1) are:

1. $46^{\circ} 56^{\prime} 40.1^{\prime \prime} \mathrm{N}, 142^{\circ} 45^{\prime} 46.7^{\prime \prime} \mathrm{E}$, alt. $135 \mathrm{~m}$, riparian secondary forest with Larix sp.

2. $46^{\circ} 56^{\prime} 40.7^{\prime \prime} \mathrm{N}, 142^{\circ} 45^{\prime} 53.9^{\prime \prime} \mathrm{E}$, alt. $103 \mathrm{~m}$, stream bank with Alnus hirsuta (Spach) Rupr., Betula platyphylla Sukaczev, Salix sachalinensis Fr. Schmidt, S. rorida Lacksch.

3. $46^{\circ} 56^{\prime} 41.2^{\prime \prime} \mathrm{N}, 142^{\circ} 45^{\prime} 56.0^{\prime \prime} \mathrm{E}$, alt. $108 \mathrm{~m}$, birch forest.

4. $46^{\circ} 56^{\prime} 41.6^{\prime \prime} \mathrm{N}, 142^{\circ} 45^{\prime} 58.2^{\prime \prime} \mathrm{E}$, alt. $115 \mathrm{~m}$, Larix sp. windfall.

5. 46 $56^{\prime} 40.6^{\prime \prime} \mathrm{N}, 142^{\circ} 46^{\prime} 01.8^{\prime \prime} \mathrm{E}$, alt. $128 \mathrm{~m}$, Larix sp. windfall. 

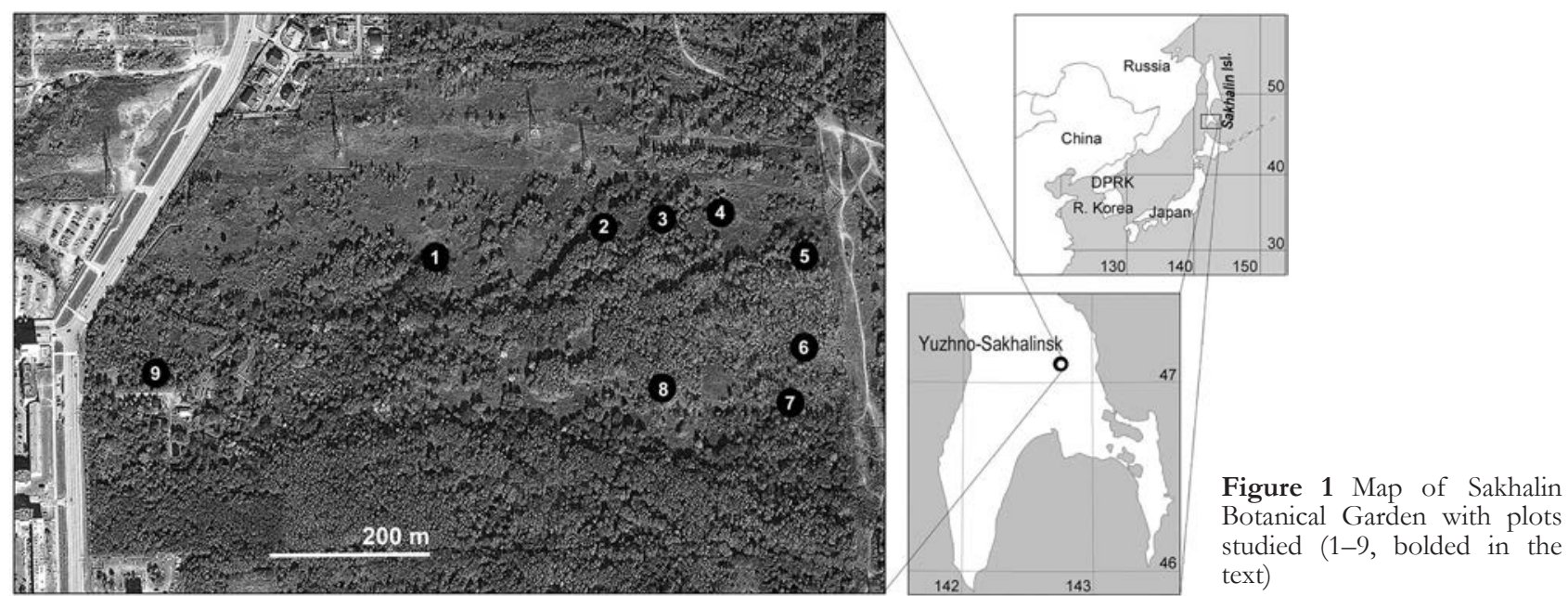

6. 46 $56^{\prime} 36.3^{\prime \prime} \mathrm{N}, 142^{\circ} 46^{\prime} 01.7^{\prime \prime} \mathrm{E}$, alt. $96 \mathrm{~m}$, stream bank with Alnus birsuta and Populus maximowiczii A. Henry.

7. 46 $56^{\prime} 34.4^{\prime \prime} \mathrm{N}, 142^{\circ} 46^{\prime} 01.7^{\prime \prime} \mathrm{E}$, alt. $90 \mathrm{~m}$, forest near stream with Betula, Alnus and Salix spp.

8. 46 $56^{\prime} 34.5^{\prime \prime} \mathrm{N}, 142^{\circ} 45^{\prime} 56.3^{\prime \prime} \mathrm{E}$, alt. $94 \mathrm{~m}$, forest with Betula sp., Alnus birsuta and Abies sachalinensis (Fr. Schmidt) Mast.

9. $46^{\circ} 56^{\prime} 35.1^{\prime \prime} \mathrm{N}, 142^{\circ} 45^{\prime} 27.3^{\prime \prime} \mathrm{E}$, alt. $62 \mathrm{~m}$, laboratory building, wooden parts.

\section{RESULTS AND DISCUSSION}

Secondary lichenological survey of the Sakhalin Botanical Garden resulted in significant enrichment of the list of lichens with species new to the areas of different scales. We provide information on the main diagnostic features for poorly understood taxa, its ecology.

\section{Species new to Russia}

Thelotrema bicinctulum Nyl. (Fig. 2A) - Russia, Far East, Sakhalin Island, Yuzhno-Sakhalinsk, Sakhalin Botanical Garden, 46 $56^{\prime} 34.5^{\prime \prime N}, 142^{\circ} 45^{\prime} 56.3^{\prime \prime} \mathrm{E}$, alt. $94 \mathrm{~m}$, forest of Betula sp., Alnus hirsuta and Abies sachalinensis (Fr. Schmidt) Mast., on bark of Abies sachalinensis, 7 May 2017, coll. S.V. Chesnokov 11: 8 (SAKH 3518).

Thallus variable in color, pale grayish-green to pale yellowish-gray. Vegetative propagules not seen in the studied specimens. Ascomata roundish, apothecia, predominantly solitary, rarely slightly fused. Disc often becomes partly visible, grayish, coarsely pruinose. Apothecial pores small, up to c. $120 \mu \mathrm{m}$ in diam., roundish to somewhat irregular, apical to upper proper exciple visible from surface, free. Proper exciple free in the upper parts, thin, internal parts hyaline, external parts pale yellowish to dark yellowish-brown. Epihymenium usually thick, hyaline, with grayish granules. Hymenium up to c. $100 \mu \mathrm{m}$ high, paraphyses unbranched with slightly thickened tips. Ascospores transversely septate, hyaline, with roundish to subacute ends, loci roundish to angular, predominantly oblong to lentiform or rectangular, with hemispherical to conical end cells, $20-35 \times 5-7 \mu \mathrm{m}$ with 8-11 loci, septa moderately thin, regular. Currently two Thelotrema species are known from Russia $-T$. bicinctulum and T. lepadinum. T. bicinctulum distinguished from more widespread T. lepadinum (Ach.) Ach. by the presence of transversely septate multicellular spores. Similar taxa in the world with transversely septate ascospores and stictic acid are T. capetribulense, T. porinoides and T. triseptatum. They can be distinguished by size of ascospores (up to $50 \mu \mathrm{m}$ with up to 14 loci in T. capetribulense, up to $35 \mu \mathrm{m}$ with up to 11 loci in T. bicinctulum, up to $140 \mu \mathrm{m}$ with up to 30 loci in T. porinoides and up to $20 \mu \mathrm{m}$ with 4 loci in T. triseptatum). Two morphologically similar, stictic acid containing species are T. cupulare and T. leucophthalmum, which are easily distinguished by muriform, non-amyloid ascospores.

It is distributed in Australia, New Caledonia (Mangold 2008), Africa (Frisch 2005), India, Sri Lanka (Hale 1981) and Andaman Islands (Nagarkar et al. 1988) (Fig. 3A).

\section{Species new to the Russian Far East}

Agonimia flabelliformis J. Halda, Czarnota \& Guz.-Krzemiń. (Fig. 2B) - Russia, Far East, Sakhalin Island, Yuzhno-Sakhalinsk, Sakhalin Botanical Garden, 46 56'34.4"N, 14246'01.7"E, alt. $90 \mathrm{~m}$, forest near stream with Betula, Alnus and Salix spp., on rotten wood of birch and mosses on stump, 7 May 2017, coll. S.V. Chesnokov 7: 7 (SAKH 3519).

It differs from closely related $A$. allobata (Stizenb.) P. James by coralliform thallus. Sterile thalli can be confused with Placynthiella icmalea (Ach.) Coppins \& P. James, which differs by darker, red-brown thalli. Fertile thalli easily distinguishable from the latter species by presence of perithecia instead of apothecia.

The species occurs on mossy bases of tree trunks and tree roots, stumps, fallen trees, also on soil, stones and plant debris in predominantly moist, shaded broad-leaved and dark coniferous-broad-leaved forests along rivers (Urbanavichus 2013). In Russia it is common in the European part: Mari-El Republic, Voronezh region (Urbanavichus 2013, Urbanavichus \& Urbanavichene 2014, Muchnik 2015), Daghestan (Ismailov et al. 2017). In the world it is known from Europe: Czech Republic, Great Britain, Germany (Guzow-Krzemińska et al. 2012), Lithuania (Motiejūnaitè \& Grochowski 2014) and Poland (Lubek 2012) (Fig. 3B).

Peridiothelia fuliguncta (Norman) D. Hawksw. - Russia, Far East, Sakhalin Island, Yuzhno-Sakhalinsk, Sakhalin Botanical Garden, 46 ${ }^{\circ} 56^{\prime} 41.2^{\prime \prime} \mathrm{N}, 142^{\circ} 45^{\prime} 56.0^{\prime \prime} \mathrm{E}$, alt. $108 \mathrm{~m}$, birch forest, on bark of Betula sp., 7 May 2017, coll. S.V. Chesnokov 4: 3 (SAKH 3520). 

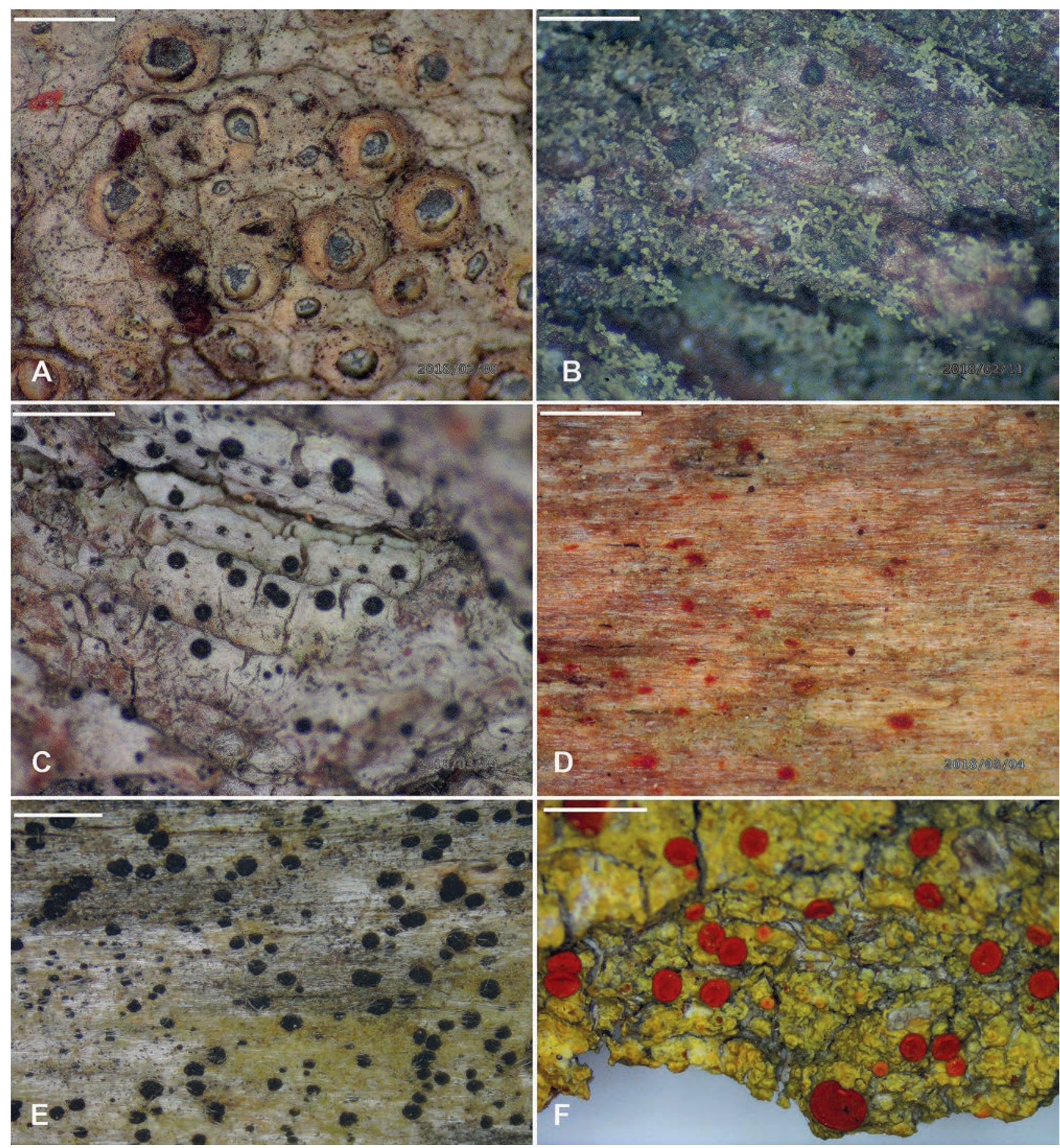

Figure 2 Some morphological traits of species: A - urceolate apothecia of Thelotrema bicinctulum, scalebar $1 \mathrm{~mm}$; B - perithecia and coralliform thallus of Agonimia flabelliformis, scalebar $1 \mathrm{~mm}$; C - perithecia of Strigula jamesii, scalebar $1 \mathrm{~mm}$; D - apothecia-like ascomata of Arthonia helvola, scalebar $1 \mathrm{~mm}$; E - apothecia of A. spadicea, scalebar $2 \mathrm{~mm} ; \mathrm{F}$ - thallus and apothecia of Caloplaca gordejevii, scalebar $2 \mathrm{~mm}$

New to the Far East. Non-lichenzed saprotrophic fungus. Main feature is absence of perithecia wall under hamathecium. In Russia sporadically occurs from the north of the European part to the Southern Siberia. Probably widespread but overlooked by researchers.

Strigula jamesii (Swinscow) R.C. Harris (Fig. 2C) - Russia, Far East, Sakhalin Island, Yuzhno-Sakhalinsk, Sakhalin Botanical Garden, 465 $56^{\prime} 40.1^{\prime \prime N}, 142^{\circ} 45^{\prime} 46.7^{\prime \prime E}$, alt. $135 \mathrm{~m}$, riparian secondary forest of Larix sp., on bark of rotten $\mathrm{Sa}$ lix sp., 7 May 2017, coll. S.V. Chesnokov 3: 1 (SAKH 3521).
It differs from closely related Strigula affinis (A. Massal.) R.C. Harris by smaller perithecia (0.1-0.2 $\mathrm{mm}$ in diam.), spores and some other characteristics (Urbanavichus 2016). New to the Russian Far East. In Russia it is known from Saint-Petersburg (Stepanchikova et al. 2015), Caucasus (Urbanavichus 2016) and Buryatia Republic (Makryi 2007). In the world: Europe - Austria, Belgium, Denmark, France, Germany, Luxembourg, Netherlands, Switzerland (Roux \& Sérusiaux 2004), Lithuania (Motiejūnaitè et al. 2012), Nor- 

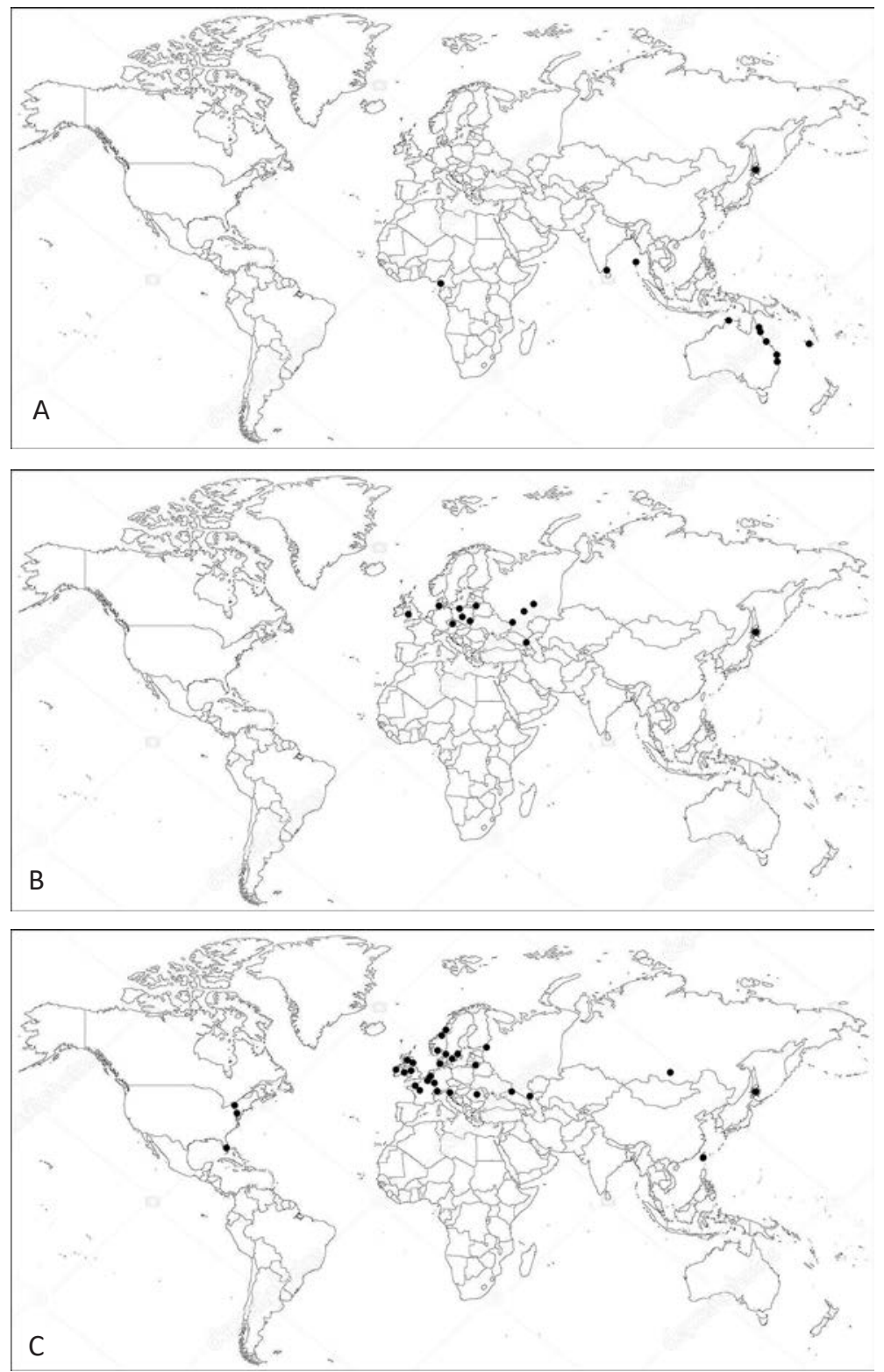

Figure 3 Distribution of Thelotrema bicinctulum (A), Agonimia flabelliformis (B) and Strigula jamesii (C)

way, Sweden (Nordin et al. 2011), Romania (Ardelean et al. 2013); Asia - Taiwan (Aptroot 2003); North America (Harris 1995, 2004, Lendemer 2008) (Fig. 3C).

\section{New to the South of the Russian Far East}

Arthonia helvola (Nyl.) Nyl. (Fig. 2D) - Russia, Far East, Sakhalin Island, Yuzhno-Sakhalinsk, Sakhalin Botanical Garden, 46 $56^{\prime} 40.1^{\prime \prime N}, 142^{\circ} 45^{\prime} 46.7^{\prime \prime E}$, alt. $135 \mathrm{~m}$, riparian secondary forest of Larix sp., on wood, 7 May 2017, coll. L.A. Konoreva 4: 1 (SAKH); Russia, Far East, Sakhalin Island, Yuzhno-Sakhalinsk, Sakhalin Botanical Garden, $46^{\circ} 56^{\prime} 36.3^{\prime \prime} \mathrm{N}, 142^{\circ} 46^{\prime} 01.7^{\prime \prime} \mathrm{E}$, alt. $96 \mathrm{~m}$, stream bank with Alnus hirsuta and Populus tremula, on bark of Alnus birsuta, 7 May 2017, coll. L.A. Konoreva 18: 6 (SAKH 3524).

Thallus thin, rugose, fine-grained to smooth, grayish, brownish, to buffy-yellow. Apothecia numerous, flat, immersed in a thallus, rusty-red. Hymenium yellow-orange to red, $\mathrm{KOH}+$ purple-violet. Spores are elongated-ellipsoidal, straight, constricted to the lower end, colorless, 3-celled, with \pm identical cells. Closely related $A$. incarnata distinguished by convex apothecia, hymenium $\mathrm{KOH}$-, and 3-celled spores with unequal ends, with a larger, almost spherical upper cell (Redinger 1937). Sporadically distributed in Russia. New to the South of the Russian Far East. The nearest locations are on Kamchatka (Neshataeva et al. 2005) and Buryatia (Baikal State reserve) (Urbanavichene \& Palice 2016).

A. spadicea Leight. (Fig. 2E) - Russia, Far East, Sakhalin, Yuzhno-Sakhalinsk, Sakhalin Botanical Garden, 46 $56^{\prime} 34.5^{\prime \prime} \mathrm{N}, 142^{\circ} 45^{\prime} 56.3^{\prime \prime} \mathrm{E}$, alt. 94 $\mathrm{m}$, forest with Betula sp., Alnus birsuta and Abies sachalinensis (Fr. Schmidt) Mast., on bark of Abies sachalinensis, 7 May 2017, coll. L.A. Konoreva 28: 8 (SAKH 3525).

Thallus immersed or thin, more or less smooth, shiny, yellowish or greenish-gray to olive. Apothecia numerous, resembling flat to slightly convex, rounded or irregularly shaped spots. Disk black, sometimes brownish, redbrown when wet. Hymenium yellow-brown, $\mathrm{KOH}+$ purple-red, $\mathrm{J}+$ reddish-brownish. Spores are elongate, colorless, 1-septate, 7-11×3-4 $\mu \mathrm{m}$, with wider rounded upper and narrowed lower cells. Closely related species are A. didyma and $A$. vinosa. $A$. didyma distinguished by larger 1 -septate spores and hymenium $\mathrm{J}+$ blue reaction. $A$. vinosa is characterized by larger spores - 11-15×4-5 $\mu \mathrm{m}$ (Redinger 1937). In Russia widely distributed in boreal forests. New to the South of the Russian Far East. The nearest known localities on Kamchatka (Himelbrant \& Kuznetsova 2004), Krasnoyarsk Territory, Republics of Tyva and Khakassia (Sedelnikova 2013).

Ionaspis epulotica (Ach.) Arnold - Russia, Far East, Sakhalin Island, Yuzhno-Sakhalinsk, Sakhalin Botanical Garden, 46 $56^{\prime} 41.6^{\prime \prime} \mathrm{N}, 142^{\circ} 45^{\prime} 58.2^{\prime \prime} \mathrm{E}$, alt. $115 \mathrm{~m}$, Larix sp. windfall, on stone, 7 May 2017, coll. L.A. Konoreva 14: 4 (SAKH 3526).

Thallus immersed or thin, wrinkled, not cracked-areolated, yellowish to pink-gray. Apothecia concave to flat, pink to pale brown, excipulum white, hardly apparent. Morphologically similar with $I$. rhodopis and $H y$ menelia prevostii. I. rhodopis distinguished by thick crackedareolated thallus and larger apothecia (0.4-0.6 mm diam.), H. prevostii - by trebouxioid photobiont (Smith et al. 2009). In Russia it occurs in Arctic and northern regions (Kristinsson et al. 2010). The nearest localities are on Kamchatka (Mikulin 1999) and Chukotka (Kristinsson et al. 2010). New to the South of the Russian Far East.

\section{New to Sakhalin Island}

Cladonia phyllophora Hoffm. - Russia, Far East, Sakhalin Island, Yuzhno-Sakhalinsk, Sakhalin Botanical Garden, 4656'40.7"N, 142 45'53.9" E, alt. 103 m, stream bank with Alnus birsuta (Spach) Rupr., Betula platyphylla Sukaczev, Salix sachalinensis Fr. Schmidt, $S$. rorida Lacksch., on bark of Betula sp., 7 May 2017, coll. L.A. Konoreva 11: 2 (SAKH 3528). 
For the Russian Far East it is known from Jewish autonomous Region, Primorsky and Khabarovsky Territories, Kamchatka (Tchabanenko 2002, Neshataeva et al. 2007, Skirina 2015a,b). It is widely distributed in the world, including Russia.

Porpidia cinereoatra (Ach.) Hertel \& Knoph (Fig. 4A) Russia, Far East, Sakhalin Island, Yuzhno-Sakhalinsk, Sakhalin Botanical Garden, 46 $56^{\prime} 41.6^{\prime \prime N}, 142^{\circ} 45^{\prime} 58.2^{\prime \prime} \mathrm{E}$, alt. 115 m, Larix sp. windfall, on stone, 7 May 2017, coll. L.A. Konoreva 13: 4 (SAKH 3599).

It is characterized by thick thallus, presence of confluentic acid and small spores $(13-18 \times 6-9 \mu \mathrm{m})$. For the South of the Russian Far East it is known from Magadan (Zheludeva 2017), Khabarovsky (Randlane 1984) and Primorsky Territories (Rodnikova 2011, Skirina 2015a) and Jewish Autonomous Region (Skirina 2015b).

P. crustulata (Ach.) Hertel \& Knoph (Fig. 4B) - Russia, Far East, Sakhalin Island, Yuzhno-Sakhalinsk, Sakhalin Botanical Garden, 46 $56^{\prime} 41.6^{\prime \prime} \mathrm{N}, 142^{\circ} 45^{\prime} 58.2^{\prime \prime} \mathrm{E}$, alt. 115 m, Larix sp. windfall, on stone, 7 May 2017, coll. L.A. Konoreva 14: 4 (SAKH 3530).

Often confused with P. macrocarpa. From that species differs by smaller apothecia and less massive proper margin that is $<0.05 \mathrm{~mm}$ wide (up to $0.2 \mathrm{~mm}$ in P. macrocarpa). For the South of the Russian Far East it is known from Jew- ish Autonomous Region (Skirina 2015b) and Khabarovsky Territories (Randlane 1984).

Pyrenula dermatodes (Borrer) Schaer. - Russia, Far East, Sakhalin Island, Yuzhno-Sakhalinsk, Sakhalin Botanical Garden, 46 56'36.3"N, 142 46'01.7"E, alt. $96 \mathrm{~m}$, stream bank with Alnus hirsuta and Populus tremula, on bark of Alnus birsuta, 7 May 2017, coll. L.A. Konoreva 22: 6 (SAKH 3522).

It is characterized by acuminate spores and perithecia partially covered with thallus (Aptroot 2012). In Russia it is known only from Primorsky Territory (Tchabanenko 2002).

Rhizocarpon reductum Th. Fr. - Russia, Far East, Sakhalin Island, Yuzhno-Sakhalinsk, Sakhalin Botanical Garden, 46 $56^{\prime} 41.6^{\prime \prime} \mathrm{N}, 142^{\circ} 45^{\prime} 58.2^{\prime \prime E}$, alt. $115 \mathrm{~m}$, Larix sp. windfall, on stone, 7 May 2017, coll. L.A. Konoreva 14: 4 (SAKH 3531)

Characterized by a brownish thallus consisting of small granules, small apothecia (up to $0.8 \mathrm{~mm}$ in diam.) with a well-developed exciple and a flat and coarse disc. R. reductum is distinguished from the closely related species ( $R$. amphibium, R. anaperum, R. lavatum, R. sublavatum) by presence of stictic acid. From R. lavatum it differs by a more subtle excipulum and relatively small spores: $20-35 \times 10-15 \mu \mathrm{m}$ (R. lavatum: $30-40 \times 14-18 \mu \mathrm{m}$ ) (Ihlen 2004). For the South of the Russian Far East it is known from Jewish Autonomous Region (Skirina 2015b) and Primorsky Territory (Cherdantseva et al. 2013). Widespread in Russia and in the world.
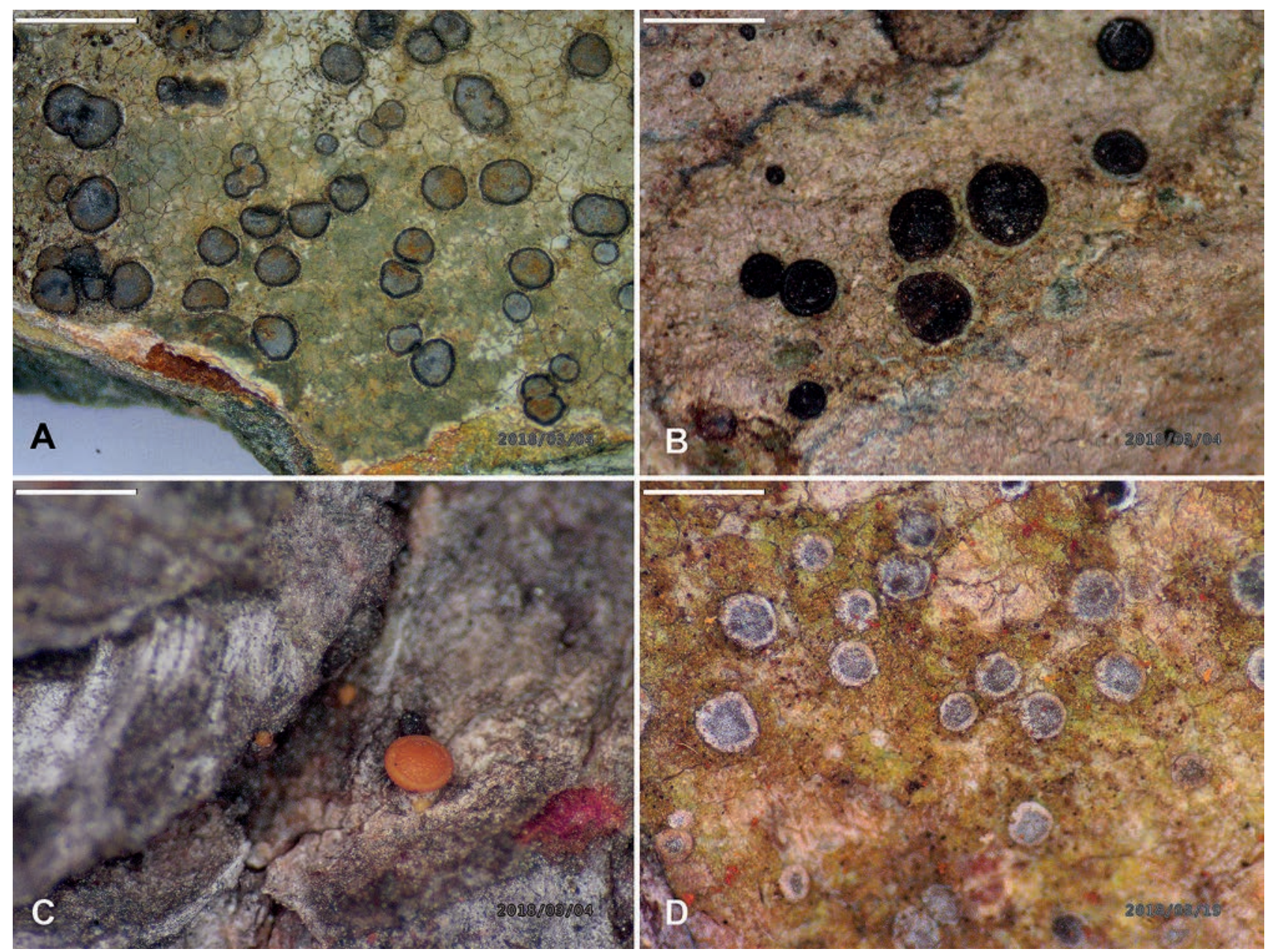

Figure 4 Some morphological traits of species: A - verrucose-areolate thallus and apothecia of Porpidia cinereoatra, scalebar $2 \mathrm{~mm}$; B - apothecia of P. crustulata, scalebar $2 \mathrm{~mm}$; C - apothecia of Sarea resinae, scalebar $1 \mathrm{~mm}$; D - apothecia and thallus patches of Lecanographa amylacea among the free-living Trentepolia sp., scalebar $1 \mathrm{~mm}$ 
Sarea resinae (Fr.: Fr.) Kuntze (Fig. 4C) - Russia, Far East, Sakhalin Island, Yuzhno-Sakhalinsk, Sakhalin Botanical Garden, 465' $56^{\prime} 40.1^{\prime \prime} \mathrm{N}, 142^{\circ} 45^{\prime} 46.7^{\prime \prime} \mathrm{E}$, alt. $135 \mathrm{~m}$, riparian secondary forest of Larix sp., on resin of Larix sp., 7 May 2017, coll. S.V. Chesnookov 1: 1 (SAKH 3532).

Non-lichenized fungus, lives on resin of coniferous trees. From $S$. diffomis it is distinguished by large red-brown or pale yellow apothecia up to $1.5 \mathrm{~mm}$ in diam. with welldeveloped, thick, exciple. For the South of the Russian Far East it is known from Jewish Autonomous Region and Primorsky Territory (Insarov \& Pchelkin 1984, Tchabanenko 2002, Skirina 2015a,b).

\section{Rare species to Sakhalin Island}

Arthonia ruana A. Massal. - Russia, Far East, Sakhalin Island, Yuzhno-Sakhalinsk, Sakhalin Botanical Garden, $46^{\circ} 56^{\prime} 40.1^{\prime \prime} \mathrm{N}, 142^{\circ} 45^{\prime} 46.7^{\prime \prime} \mathrm{E}$, alt. $135 \mathrm{~m}$, riparian secondary forest of Larix sp., on bark of Alnus hirsuta, 7 May 2017, coll. L.A. Konoreva 5: 1 (SAKH); Russia, Far East, Sakhalin Island, Yuzhno-Sakhalinsk, Sakhalin Botanical Garden, 46 $56^{\circ} 36.3^{\prime \prime} \mathrm{N}, 142^{\circ} 46^{\prime} 01.7^{\prime \prime} \mathrm{E}$, alt. $96 \mathrm{~m}$, stream bank with Alnus hirsuta and Populus tremula, on bark of Alnus birsuta, 7 May 2017, coll. L.A. Konoreva 22: 6 (SAKH); Russia, Far East, Sakhalin Island, Yuzhno-Sakhalinsk, Sakhalin Botanical Garden, 46 $56^{\prime} 34.4^{\prime \prime} \mathrm{N}, 142^{\circ} 46^{\prime} 01.7^{\prime \prime} \mathrm{E}$, alt. $90 \mathrm{~m}$, forest near stream with Betula, Alnus and Salix spp., on bark of Alnus hirsuta and fallen trees, 7 May 2017, coll. L.A. Konoreva 24, S.V. Chesnokov 6: 7 (SAKH 3533).

The second records for Sakhalin Island. The species was mentioned for the first time by Ezhkin \& Schumm (in print).

Bryobilimbia hypnorum (Lib.) Fryday et al. - Russia, Far East, Sakhalin Island, Yuzhno-Sakhalinsk, Sakhalin Botanical Garden, 46 56'34.4"N, 14246'01.7"E, alt. 90 m, forest near stream with Betula, Alnus and Salix spp., on rotten birch stump, 7 May 2017, coll. S.V. Chesnokov 7: 7 (SAKH 3534).

The second record for Sakhalin Island. The species was mentioned for the first time by Ezhkin \& Schumm (in print).

Caloplaca gordejevii (Tomin) Oxner (Fig. 2F) - Russia, Far East, Sakhalin Island, Yuzhno-Sakhalinsk, Sakhalin Botanical Garden, 465' 40.1 'N, 14245'46.7'E, alt. 135 m, riparian secondary forest of Larix sp., on the bark of rotten Salix sp., 7 May 2017, coll. S.V. Chesnokov 3: 1 (SAKH 3527).

The species is closely related to $C$. flavorubescens, from which it differs by short bacilliform conidia $(2.0-2.5 \times 0.5-$ $0.8 \mu \mathrm{m})$, dark-orange to ferruginous-red apothecia with concolorous proper margin. It was found in Sakhalin by Ezhkin \& Galanina (2016). In Russia it is known only from the Far East - Primorsky and Khabarovsky Territories (Tchabanenko 2002, Galanina 2010) and Kamchatka (Khodosovtsev et al. 2004).

Cliostomum corrugatum (Ach.: Fr.) Fr. - Russia, Far East, Sakhalin Island, Yuzhno-Sakhalinsk, Sakhalin Botanical Garden, 4656'41.6"N, 142 $45^{\prime} 58.2^{\prime \prime E}$, alt. 115 m, Larix sp. windfall, on bark of Betula sp., 7 May 2017, coll. S.V. Chesnokov 4: 3 (SAKH 3535).

Third location for Sakhalin Island. The species was mentioned for the first time from the Korsakovsky district and Yuzhno-Sakhalinsk city (Konoreva et al. in print).

Lecanographa amylacea (Ehrh. ex Pers.) Egea \& Torrente (Fig. 4D) - Russia, Far East, Sakhalin Island, Yuzh-
no-Sakhalinsk, Sakhalin Botanical Garden, 4656'36.3"N, $142^{\circ} 46^{\prime} 01.7^{\prime \prime E}$, alt. $96 \mathrm{~m}$, stream bank with Alnus birsuta and Populus tremula, on bark of Alnus birsuta, 7 May 2017, coll. L.A. Konoreva 22: 6 (SAKH); Russia, Far East, Sakhalin Island, Yuzhno-Sakhalinsk, Sakhalin Botanical Garden, 4656'34.4"N, 142 $46^{\circ} 01.7^{\prime \prime} \mathrm{E}$, alt. $90 \mathrm{~m}$, forest near stream with Betula, Alnus and Salix spp., on bark of Alnus birsuta, 7 May 2017, coll. S.V. Chesnokov 8: 7 (SAKH); Russia, Far East, Sakhalin Island, Yuzhno-Sakhalinsk, Sakhalin Botanical Garden, 46 $56^{\prime} 34.5^{\prime \prime} \mathrm{N}, 142^{\circ} 45^{\prime} 56.3^{\prime \prime} \mathrm{E}$, alt. $94 \mathrm{~m}$, forest with Betula sp., Alnus hirsuta and Abies sachalinensis (Fr. Schmidt) Mast., on bark of Abies sachalinensis, 7 May 2017, coll. L.A. Konoreva 28, S.V. Chesnokov 11: 8 (SAKH 3536).

Second locality for Sakhalin Island. The species was mentioned for the first time from the Yuzhno-Sakhalinsk city (Konoreva et al. in print).

Lecidea albobyalina (Nyl.) Th. Fr. - Russia, Far East, Sakhalin Island, Yuzhno-Sakhalinsk, Sakhalin Botanical Garden, $46^{\circ} 56^{\prime} 40.1^{\prime \prime N}, 142^{\circ} 45^{\prime} 46.7^{\prime \prime} \mathrm{E}$, alt. $135 \mathrm{~m}$, riparian secondary forest with Larix sp., on bark of rotten Salix sp., 7 May 2017, coll. S.V. Chesnokov 3: 1 (SAKH 3537).

Second location for Sakhalin Island. The species was mentioned for the first time by Ezhkin \& Schumm (in print).

Lecidea berengeriana (A. Massal.) Th. Fr. - Russia, Far East, Sakhalin Island, Yuzhno-Sakhalinsk, Sakhalin Botanical Garden, 4656'36.3"N, 142 46'01.7"E, alt. $96 \mathrm{~m}$, stream bank with Alnus hirsuta and Populus tremula, on bark of Betula sp., 7 May 2017, coll. L.A. Konoreva 20: 6 (SAKH 3538).

Third location for Sakhalin Island. The species was mentioned for the first time from the Korsakovsky district and Yuzhno-Sakhalinsk city (Konoreva et al. in print).

Stenocybe pullatula (Ach.) Stein - Russia, Far East, Sakhalin Island, Yuzhno-Sakhalinsk, Sakhalin Botanical Garden, 46 $56^{\prime} 36.3^{\prime \prime} \mathrm{N}, 142^{\circ} 46^{\prime} 01.7^{\prime \prime} \mathrm{E}$, alt. $96 \mathrm{~m}$, stream bank with Alnus hirsuta and Populus tremula, on bark of Alnus hirsuta, 7 May 2017, coll. L.A. Konoreva 19: 6 (SAKH 3539).

Saprotrophic fungus, lives on bark and branches of Alnus sp. It is characterized by small apothecia $(0.09-0.1 \mathrm{~mm}$ in diam.) on branched stalks and narrow ellipsoid light smooth spores that long remaining unicellular (Titov 2006). Second location for Sakhalin Island. The species was mentioned for the first time by Titov (2006) from Poronaysky reserve.

Strigula stigmatella (Ach.) R.C. Harris - Russia, Far East, Sakhalin Island, Yuzhno-Sakhalinsk, Sakhalin Botanical Garden, 4656'36.3"N, 14246'01.7"E, alt. $96 \mathrm{~m}$, stream bank with Alnus birsuta and Populus maximowiczii A. Henry, on bark of Populus maximowicziii, 7 May 2017, coll. L.A. Konoreva 17: 6 (SAKH 3540).

Second location for Sakhalin Island. The species was mentioned for the first time from the Tymovsky district (Konoreva et al. in print).

\section{ACKNOW LEDGEMENTS}

The work was carried out within the institutional project of Botanical Garden-Institute FEB RAS “Cryptogamic biota of Pacific Asia: taxonomy, biodiversity, species distribution". We are grateful to Ivan Frolov (Botanical Garden of the Urals Branch of Russian Academy of Sciences, Ekaterinburg) for the discussion of the manuscript. 


\section{LITERAT URE CITE D}

Ardelean, I.V., C. Keller \& C. Scheidegger 2013. Lichen flora of Rodnei Mountains National Park (Eastern Carpathians, Romania) including new records for the Romanian mycoflora. Folia Cryptogamica Estonica 50:101-115.

Aptroot, A. 2003. Pyrenocarpous lichens and related nonlichenised ascomycetes from Taiwan. Journal of the Hattori Botanical Laboratory 93:155-173.

Aptroot, A. 2012. A world key to the species of Anthracothecium and Pyrenula. The Lichenologist 44(1):5-53.

Cherdantseva, V.Ya., V.A. Bakalin, L.S. Yakovchenko \& S.S. Choi 2013. Bryophyte flora and lichen biota of Litovka Mt. (Livadiysky range, Russian Manchuria). Komarovskie chteniya 61:9-49 (in Russian with English summary). [ЧepАанцева В.Я., Бакалин В.А., Яковченко А.С., Чой С.С. 2013. Бриофлора и михенобиота горы Аитовка (Аивадийский хребет, российская Маньчжурия) // Комаровские чтения. Вып. 61. С. 9-49].

Ezhkin, A.K. \& I.A. Galanina 2016. Epiphytic lichens of deciduous trees in the city of Yuzhno-Sakhalinsk and specifics of their distribution by sensitivity to the anthropogenic impact. Vestnik Severo-Vostochnogo nauchnogo tsentra DVO RAN 4:95-107 (in Russian with English summary). [Ежкин А.К., Галанина И.А. 2016. Эпифитные мишайники миственных Аеревьев г. Южно-Сахалинск и особенности их распределения по степени чувствительности к антропогенному воздействию // Вестник Северо-Восточного научного центра $\triangle \mathrm{BO}$ РАН. № 4. C. 95-107].

Ezhkin, A. \& F. Schumm 2018. New and noteworthy lichen and allied fungi records from Sakhalin Island, Far East of Russia II. Folia Cryptogamica Estonica (in print).

Frisch, A. 2005. Contributions towards a new systematics of the lichen family Thelotremataceae. I. The lichen family Thelotremataceae in Africa. A revision with special consideration of the taxa from Cameroon and Tanzania. Bibliotheca Lichenologica 92:3-370.

Galanina, I.A. 2010. Geographical distribution and habitats of lichen Caloplaca gordejevi (Tomin) Oxner ex Khodos. Bulleten' Botanicheskogo sada-instituta DVO RAN 7:121-125 (in Russian with English summary). [Галанина И.А. 2010. Географическое распространение и экологическая приуроченность мишайника Caloplaca gordejevi (Tomin) Oxner ex Khodos. // Бюмлетень Ботанического садаинститута АВО РАН. Вып. 7. С. 121-125].

Galanina, I.A. 2013. Lichens of fir-spruce and larch forests with Sasa kurilensis (Rupr.) Makino \& Shibata in undergrowth shrub layer on south of Sakhalin Island. Vestnik Severo-Vostochnogo nauchnogo tsentra DVO RAN 2(34):86-94 (in Russian). ГГаланина И.А. 2013. Аи-

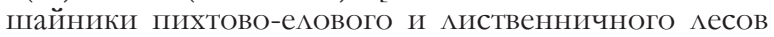
с подлеском из бамбука курильского на юге острова Саха^ин // Вестник Северо-Восточного научного центра АВО РАН. № 2. Вып. 34. С. 86-94].

Guzow-Krzemińska, B., J.P. Halda \& P. Czarnota 2012. A new Agonimia from Europe with a flabelliform thallus. The Lichenologist 44(1):55-66.

Hale, M.E. 1981. A revision of the lichen family Thelotremataceae in Sri Lanka. Bulletin of the British Museum (Natural History), Botany 8:227-332.

Harris, R.C. 1995. More Florida lichens, including the 10 et tour of the pyrenolichens. New York Botanical Garden, Bronx, USA, 180 pp.

Harris, R.C. 2004. A preliminary list of the lichens of New York. Opuscula Philolichenum 1:55-74.

Himelbrant, D.E. \& E.S. Kuznetsova 2004. History of lichen investigations and problems of including species in Red Data Book of Kamchatka region. In: Reports of the 5 th scientific conference "Conservation of biodiversity of Kamchatke and coastal waters», pp. 29-32, Petropavlovsk-Kamchatskiy, 22-24 November 2004 (in Russian with English summary). [Гимельбрант А.Е., Кузнецова Е.С. 2004. История изучения мишайников Камчатки и проблемы вкАючения видов в Красную книгу Камчатской области / / Материалы V научной конференции «Сохранение биоразнообразия Камчатки и примегающих морей». Петропав оовск-Камчатский, 22-24 ноября 2004 г. С. 29-32].

Ihlen, P.G. 2004. Taxonomy of the non-yellow species of Rhizocarpon (Rhizocarpaceae, lichenized Ascomycota) in the Nordic countries, with hyaline and muriform ascospores. Mycological Research 108(5):533-570.

Insarov, G.E. \& A.V. Pchelkin 1984. Quantitative characteristics of the state of epiphytic lichen flora of biosphere reserves. SiboteAlins nature reserve, vol. 2. Moscow, 70 pp. (in Russian). [Инсаров Г.Э., Пчелкин А.В. 1984. Количественные характеристики состояния эпифитной михенофморы биосферных заповедников. Сихотэ-Алинский заповедник. М.: Гос. комитет СССР по гидрометеоромогии и контролю природной среды. Вып. 2.70 c].

Ismailov A., G. Urbanavichus, J. Vondrák \& V. Pouska 2017. An old-growth forest at the Caspian Sea coast is similar in epiphytic lichens to lowland deciduous forests in Central Europe. Herzogia 30(1):103-125.

Khodosovtsev, A., E. Kuznetzova \& D. Himelbrant 2004. Lichen genus Caloplaca on the Kamchatka Peninsula (Russian Far East). Botanica Lithuanica 10(3):195-208.

Konoreva, L., S. Tchabanenko, A. Ezhkin, F. Schumm \& S. Chesnokov 2018. New and noteworthy lichen and allied fungi records from Sakhalin Island, Far East of Russia. Herzogia 31(1) (in print).

Kristinsson, H., M. Zhurbenko, \& E.S. Hansen 2010. Panarctic checklist of lichens and lichenicolous fungi. $C A F F$ Technical Report 20:1-120.

Lendemer, J. 2008. New and interesting records of lichens and lichenicolous fungi from New Jersey and Pennsylvania. Evansia 25(4):102-109.

Lubek, A. 2012. Agonimia species and other rare lichens in Central Poland. Acta Mycologica 47(2):203-212.

Makryi, T.V. 2007. Lichens of Ulmus japonica forests in western and eastern Transbaikalia. Sibirskii ekologicheskii zhurnal 14(6):951-960 (in Russian with English summary). [Макрый Т.В. 2007. Аишайники ильмовников из Ulmus japonica Западного и Восточного Забайкалья // Сибирский экологический журнал. Т. 14, № 6. С. 951-960].

Mangold, A. 2008. Taxonomic studies on members of thelotrematoid Ostropales (lichenized Ascomycota) in Australia. Inaugural-Dissertation zur Erlangung des Doktorgrades Dr. rer. nat. des Fachbereichs Biologie und Geografie an der Universität Duisburg-Essen. Stuttgart. 327 pp.

Mikulin, A.G. 1999. A guide to lichens of Kamchatka Peninsula. Vladivostok, 125 pp. (in Russian). [Микулин А.Г. 1990. Определитель мишайников полуострова Камчатка. ВАадивосток, 125 с.].

Motiejūnaite, J. \& P. Grochowski 2014. Miscellaneous new records of lichens and lichenicolous fungi. Herzogia 27(1):193-198.

Motiejūnaite, J., T. Berglund, P. Czarnota, D. Himelbrant, F. Högnabba, L.A. Konoreva, E.S. Korchikov, D. Kubiak, M. Kukwa, E. Kuznetsova, E. Leppik, P. Lõhmus, I.P. Lukošienè, J. Pykälä, D. Stončius, I. Stepanchikova, A. Suija, A. Thell, A. Tsurykau \& M. Westberg 2012. Lichens, lichenicolous and allied fungi found in Asveja Regional park (Lithuania). Botanica Lithuanica 18(2):85-100. 
Muchnik, E.E. 2015. Lichens as indicators of forest ecosystems in central European Russia. Lesotehnicheskii z.hurnal 3:65-76 (in Russian with English summary). [Мучник Е.Э. 2015. Аишайники как индикаторы состояния месных экосистем центра европейской России / / $\Lambda$ eсотехнический журнам. Вып. 3. С. 65-76].

Nagarkar, M.B., P.K. Sethy \& P.G. Patwardhan 1988. Lichen genus Ocellularia (Family Thelotremataceae) from India. Biovigyanam 14:24-43.

Neshataeva, V.Yu., I.V. Chernyadjeva, D.E. Himelbrant, E.S. Kuznetsova, V.Yu. Neshatayev, O.A. Chernyagina \& M.V. Dulin 2005. Pristine riparian forests of southwest Kamchatka (species composition and the community characteristics). In: Reports of the 5 th scientific conference "Conservation of biodiversity of Kamchatke and coastal wa-ters», pp. 70-102, Petropavlovsk-Kamchatskiy, 22-24 November 2004. (in Russian with English summary). [Нешатаева В.Ю., Чернядьева И.В., Гимельбрант А.Е., Кузнецова Е.С., Нешатаев В.Ю., Чернягина О.А., Аулин М.В. 2005. Пойменные меса юго-западной Камчатки (фмористическая и фитоценотическая характеристика) / / Материалы V научной конференции «Сохранение биоразнообразия Камчатки и прилегающих морей». Петропавловск-Камчатский, 22-24 ноября 2004 г. C. 70-102].

Neshataeva, V.Yu., M.P. Vyatkina, L.B. Golovneva, D.E. Himelbrant, I.V. Chernyadjeva, A.A. Oskolsky \& I.S. Stepanchikova 2007. Poplar woodlands on the volcanic deposits of Tolbachinsky dol in the Kluchevskaya group of volcanoes (Central Kamchatka). In: Proceedings of 7 th international scientific conference "Conservation of biodiversity of Kamchatke and coastal waters», Pp. 92-119, PetropavlovskKamchatskiy, 28-29 November 2006 (in Russian with English summary). [Нешатаева В.Ю., Вяткина М.П., Головнева А.Б., Гимельбрант А.Е., Чернядьева И.В., Оскольский А.А., Степанчикова И.С. 2007. Тополевые редколесья на вулканических отложениях Толбачинского АОАа в КАючевской группе вулканов (Центральная Камчатка) // Аоклады VII международной научной конференции «Сохранение биоразнообразия Камчатки и прилегающих морей». Петропавмовск-Камчатский, 28-29 ноября 2006 г. С. 92-119].

Nordin, A., R. Moberg, T. Tønsberg, O. Vitikainen, A. Dalsätt, M. Myrdal, D. Snitting \& S. Ekman 2011 Santesson's checklist of lichen-forming and lichenicolous fungi. Version 29 April 2011. Uppsala, Sweden. Available at http://130.238.83.220/santesson/home.php, last accessed 27.04.2018.

Randlane, T. 1984. About lichens of alpine zone of Badzhal range (Khabarovsk territory). In: Flora i gruppirovki niashih rastenii v prirodnyh $i$ antropogennyh ekstremalnyh usloviyah sredy, pp. 120-133. Tallin (in Russian). РРандлане T. 1984. О Аишайниках гольцового пояса хребта Баджац (Хабаровский край) // Фцора и группировки низших растений в природных и антропогенных экстремальных условиях среды. Тамлин, 1984. С. 120-133].

Redinger, K. 1937. Familie Arthoniaceae. Rabenhorst Kryptogamenflora 9:1-180.

Rodnikova, I.M. 2011. Materials to the study of lichens from Russky Island and the near small islands (Peter the Great Bay, Sea of Japan). Turczaninowia 14(3):94-99 (in Russian with English summary). [Родникова И.М. 2011. Материалы к изучению мишайников острова Русский и близлежащих малых островов (залив Петра Великого, Японское море) // Turczaninowia. T. 14, № 3. C. 94-99].

Roux, C. \& E. Sérusiaux 2004. Le genre Strigula (Lichens) en Europe et en Macaronésie. Bibliotheca Lichenologica 90:3-96.
Sedelnikova, N.V. 2013. Species diversity of lichen biota of the Altai-Sayan ecological region. Rastitelnyi mir Aziatskoy Rossii 2(12):12-54 (in Russian with English summary). [Седельникова Н.В. 2013. Видовое разнообразие лихенобиоты А^тае-Саянского экорегиона // Растительный мир Азиатской России. № 2(12). С. 12-54].

Skirina, I.F. 2015a. List of lichens of Sikhote-Alin nature reserve (Russia). Biota $i$ sreda zapovednikov Dal'nego Vostoka 3:10-102 (in Russian with English summary). [Скирина И.Ф. 2015а. Список мишайников СихотэА^инского заповедника // Биота и среда заповедников АаАьнего Востока. № 3. С. 10-102].

Skirina, I.F. 2015b. Lichen list of "Bastak" nature reserve (Russia). Biota i sreda zapovednikov Dal'nego Vostoka 4:2887 (in Russian with English summary). [Скирина И.Ф. 2015b. Список Аишайников заповедника «Бастак» // Биота и среда заповедников Аальнего Востока. № 4. C. 28-87].

Smith, C.W., A. Aptroot, B.J. Coppins, A. Fletcher, O.L. Gilbert, P.W. James, \& P.A. Wolseley 2009. The lichen flora of Great Britain and Ireland. British Lichen Society, London. 1046 p.

Stepanchikova, I.S., D.E. Himelbrant, A.V. Dyomina \& G.M. Tagirdzhanova 2015. The lichens and allied fungi of the Zapadny Kotlin Protected Area and its vicinities (Saint Petersburg). Novosti sistematiki nizshikh rastenii 49: 265-281. [Степанчикова И.С., Гимельбрант А.Е., Аёмина А.В., Тагирджанова Г.М. 2015. Аихенофлора заказника «Западный Котлин» и его окрестностей (Санкт-Петербург) // Новости систематики низших растений. Т. 49. С. 265-281].

Tchabanenko, S.I. 1999. Epiphytic lichens of the Sakhalin Botanical Garden. Trudy botanicheskib sadov DVO RAN 1: 34-37 (in Russian with English summary). [Чабаненко С.И. 1999. Аишайники-эпифиты СахаАинского ботанического сада АВО РАН // Труды ботанических садов $\triangle$ ВО РАН. Т.1. C. 34-37].

Tchabanenko, S.I. 2002. Checklist of the flora of lichens in the south of the Russian Far East. Dalnauka, Vladivostok, 232 pp. (in Russian). [Чабаненко С.И. 2002. Конспект

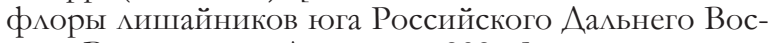
тока. ВАадивосток: Аальнаука. 232 с.].

Titov, A.N. 2006. Mycocaliciod fungi (the order Mycocaliciales) of the Holarctic. KMK Scientific Press, Moskow, 296 pp. (in Russian). [Титов А.Н. 2006. Микокалициевые грибы (порядок Mycocaliciales) Голарктики. М.: Товарищество научных изАаний КМК. 296 с.].

Urbanavichene, I.N. \& Z. Palice 2016. Rarely recorded lichens and lichen-allied fungi from the territory of the Baikal Reserve - additions for lichen flora of Russia. Turcraninowia 19(1):42-46.

Urbanavichus, G.P. 2013. Family Verrucariaceae in Russia. I. Genus Agonimia. Novosti sistematiki nizshikh rastenii 47:279-296 (in Russian with English summary). [Урбанавичюс Г.П. 2013. Семейство Verrucariaceae в России. I. Род Agonimia // Новости систематики низших растений. Т. 47. С. 279-296].

Urbanavichus, G.P. 2016. The genus Srtigula (Strigulaceae, Strigulales) in the lichen flora of the Caucasus. Botanicheskii Zhurnal 101(2):154-166 (in Russian with English summary). [Урбанавичюс Г.П. 2016. РоА Srtigula (Strigulaceaea, Strigulales) в михенофморе Кавказа // Ботанический журнал. Т. 101, №2. С. 154-166].

Urbanavichus, G.P. \& I.N. Urbanavichene 2014. The first addition to the lichenflora of the Republic of Mordovia and Middle Russia. Byulleten moskovskogo obshchestva ispytatelei prirody. Otdelenie biologii 119(3):78-81 (in Russian with English summary). [Урбанавичюс Г.П., Урбанавичене И.Н. 2014. Первое Аополнение к лихенофлоре Рес- 
публики Мордовия и Средней России // Бюлцетень московского общества испытателей природы. ОтАемение биологии. Т. 119. Вып. 3. С. 78-81].

Zheludeva, E.V. 2017. New records of lichen species from
Magadan region. Turczaninowia 20(2):64-74 (in Russian with English summary). [Желудева Е.В. 2017. Новинки михенофлоры МагаАанской области // Turczaninowia. T. 20, №2. C. 64-74]. 